\title{
Mesoporous Silica with Covalently Immobilized Anthracene as Adsorbent for SPE Recovery of PAHs Pollutants from Highly Lipidic Solutions
}

\author{
Albina Mikhraliieva ${ }^{\dagger}, R^{\prime}$ odrigo A. Gonçalves ${ }^{\dagger}$, Vladimir Zaitsev ${ }^{* \ddagger \ddagger}$ \\ † Pontifical Catholic University of Rio de Janeiro, 38097, Rio de Janeiro, Marquês de Sao Vicente Street, 225, Brazil; \\ *e-mail: vnzaitsev@puc-rio.br; \\ ‡ National University of Kyiv-Mohyla Academy, 2 Skovorody vul., Kyiv, 04070, Ukraine
}

Recieved: November 05, 2020; Accepted: February 08, 2021

DOI: 10.17721/moca.2021.5-14

\begin{abstract}
Two samples of functionalized mesoporous silica containing anchored anthrylmethylamine groups $\left(\mathrm{SiO}_{2}\right.$-Ant) have been prepared by surface assembling (1) and one step silane immobilization (2). Both adsorbents can be attributed to bimodal balanced hydrophobic-hydrophilic adsorbents with loading of anthracene groups about $15-33 \%$. The adsorbents have been used for solid-phase extraction (SPE) of anthracene from organic solvents (acetonitrile, acetone and heptane) and model solutions of lipids (myristic acid and vegetable oil). The obtained results were compared with commercial C18 SPE cartridge. While C18 cartridge recovers anthracene from water-containing media (acetonitrile/water, 1/1), $\mathrm{SiO}_{2}$-Ant cartridges much more efficient in extraction of anthracene from non-polar solvent (heptane). Lipids macrocomponents such as myristic acid and vegetable oil do not decrease the dynamic adsorption capacity and recovery of the model polycyclic aromatic hydrocarbon (PAH) on $\mathrm{SiO}_{2}$-Ant. It was demonstrated that $\pi$ - $\pi$ stacking interaction with the analyte determine the selectivity of $\mathrm{SiO}_{2}$-Ant towards of anthracene. This makes $\mathrm{SiO}_{2}$-Ant attractive for selective preconcentration of PAHs from high lipid content objects, such as vegetable oils.
\end{abstract}

Keywords: PAHs, Anthracene, stacking interaction, PAH-selective adsorbents

\section{Мезопоруватий кремнезем із ковалентно іммобілізованим антраценом як адсорбент для ТФЕ вилучення забруднювачів ПАУ з розчинів із високим вмістом ліпідів}

\author{
Альбіна Міхралієва ${ }^{\dagger}$, Родріго А. Гонсалвес ${ }^{\dagger}$, Володимир Зайцев ${ }^{\star \ddagger}$ \\ † Папський католицький університет Ріо-де-Жанейро, 38097, Ріо-де-Жанейро, вул. Маркеса де Сан-Вісенте, 225, \\ Бразилія; *e-mail: vnzaitsev@puc-rio.br; \\ ‡ Національний університет «Києво-Могилянська академія», вул. Сковороди 2, Київ, 04070, Україна
}

Надійшла: 05 листопада 2020 р; Прийнята: 08 лютого 2021 р

DOI: $10.17721 /$ moca.2021.5-14

\begin{abstract}
Два зразки ффунціоналізованого мезопоруватого кремнезему із закріпленими групами анрилметиламіну ( $\mathrm{SiO}_{2}$-Ant) були отримані шляхом збирання на поверхні (1) та одностадійною іммобілізацією силану (2). Обидва адсорбенти можуть бути віднесені до бімодальних збалансованих гідрофобногідрофрільних адсорбентів із вмістом 15-33\% антраценових від загальної кількості іммобілізованих груп. Адсорбенти були застосовані для твердофразно-екстакційного (SPE) вилучення антрацену, як модельного представника класу поліциклічних ароматичних вуглеводнів (ПАУ), з органічних (ацетонітрил, ацетон, гептан) та водно-органічних (ацетонітрил-вода) розчинів ліпідів (міристинова кислота та рослинна олія). Результати були зіставлені з отриманими на комерційному С18 картриджі. $\mathrm{SiO}_{2}$-Ant набагато ефрективніше екстрагує антрацен із неполярного розчинника (гептан), тоді як С18 краще адсорбує антрацен з водовмісних середовищ, (ацетонітрил/вода). Досліджені макрокомпоненти ліпідів не зменшують динамічну адсорбційну ємність та ступінь визначення модельного ПАУ на $\mathrm{SiO}_{2}$-Ant. Було продемонстровано, що утворення п-п стекінгу з аналітом визначає спорідненість $\mathrm{SiO}_{2}$-Ant по відношенню до антрацену. Таким чином SiO - -Ant є перспективним адсорбентом для селективного концентрування ПАУ з розчинів із високим вмістом ліпідів, таких як рослинна олія.
\end{abstract}

Ключові слова: ПАУ, Антрацен, стекінг взаємодія, ПАУ-селективний адсорбент 
Polycyclic aromatic hydrocarbons (PAHs) are a group of more than 100 chemicals having aromatic rings. Most of them are persistent organic pollutants. PAHs are capable to stick tightly to soil particles and contaminate underground water. Many of PAHs have carcinogenic properties and thus water quality control requires their determination in complex matrix [1]. Also, because of the high lipophilicity, PAHs can easily contaminate vegetable oils and animal fat [2]. These dangerous chemicals accumulate in marine organisms and through the food chain can contaminate human body [3]. Most common analytical practice of PAHs determination is high performance liquid chromatography with fluorescence detection (HPLC-FLD) [4,5] or gas chromatography mass spectrometry (GC-MS) analysis [6] that requires advances in sample preparation. Particularly, determination of PAHs in fats and oils requires saponification of the samples with $\mathrm{KOH}$ in methanol with further exhausting liquid-liquid extraction (LLE) and cleaning on a silica or/and alumina packed column $[4,7,8]$ The objective of this clean-up procedure is to remove polar macrocomponents. It is obvious that such approach is not optimized for determination of PAHs in high-lipid matrix since requires application of large columns [9] that can lead to essential loses of the analyte traces due to their unspecific adsorption on silica/alumina [10-12]. Also, due to incomplete hydrolysis, triglycerides and fatty acids can contaminate the extract that can affect the detection limit of PAHs [2,13,14]. Finally, large volumes of solvents used in LLE increase potential of the analyte contamination with interfering impurities [12]. All these obstacles make the analysis of PAHs in high-lipid matrix low reliable, long and expensive.

To improve the sample preparation procedure several new types of adsorbents were proposed for solid-phase extraction (SPE) $[8,15]$. It is clear that such common adsorbent as C18-functionalised silica gel (C18), which perfectly works for pre-concentration of PAHs from water-containing media [8], is unsuitable in lipid media since it is non-selective and can be easily saturated with components of lipophilic matrix [8]. Thus, more hydrophilic adsorbents than C18 are required for improving recovery of PAHs from lipidic matrix. For example, commercially available hydrophilic-lipophilic balanced polymers (Oasis HLB) demonstrated better selectivity towards PAHs than C18 adsorbent [8]. Other approach is molecularly imprinted polymers. Because of their rigid structure PAHs can form specific cavities in the adsorbent matrix. Such type of adsorbent is very specific due to their shape-selectivity [1]. The most promising direction in development of PAHs-selective adsorbent which are capable for specific interaction with them. The specific feature of PAHs is conjugated system of $\pi$-electrons which enables specific intermolecular interaction with other molecules having conjugated system of electrons [16]. For example, aryl-modified silica gel demonstrates essential affinity towards PAHs due to such $\pi-\pi$ interaction $[15,17]$. Similar effect can explain moderate affinity of hyper-crosslinked polystyrene resin and porphyrin-containing polymers [18] towards PAHs. Most recently hybrid materials containing carbon nanomaterials such as graphene [19] and multiwall carbon nanotubes [20] have been explored for adsorption of PAHs.

As it can be seen from above, rational design of the adsorbent surface that balance it lipophilicity and affinity towards PAHs is crucial. In this research preparation of anthracene-functionalized silica gel $\left(\mathrm{SiO}_{2}-\mathrm{Ant}\right)$ is reported. To manage hydrophilic-lipophilic balance of the adsorbent as well as its potential to form $\pi$-complexes with PAHs two-different synthetic approaches were explored. Also, different silica gel matrixes with pore size varied from 6 to $11 \mathrm{~nm}$ have been investigated as the support. It was allowed to control the anthracene loading and the materials lipophilicity. Adsorption properties of the $\mathrm{SiO}_{2}$-Ant were studied for model solution of PAHs in water, acetone and heptane, as well as for contaminated vegetable oil in SPE mode.

\section{Materials and methods}

Chemicals and solutions. Silica gels with pore size (d) 6 and $11 \mathrm{~nm}$, annotated as $\mathrm{SiO}_{2}(6)$ and $\mathrm{SiO}_{2}(11)$, respectively, (3-Aminopropyl)triethoxysilane (APTES, $\geq 98 \%$ ), toluene anhydrous, diglyme, N-[3(Trimethoxysilyl)propyl]ethylenediamine (EDAS), $\mathrm{N}, \mathrm{N}$-Diisopropylethylamine (DIPEA), 9-(chloromethyl) anthracene (9CMA), 9-Anthracenecarboxaldehyde (9ACA), anthracene (Ant), acetonitrile ( $\mathrm{MeCN}, \geq 99 \%)$, sodium borohydride (NaBH4, 99\%) were purchased from Sigma-Aldrich (USA). Ninhydrin (99\%) were from QHEMIS (Brazil). Anthracene was recrystallized from acetone. Toluene was kept in a dark bottle over $3 \AA$ molecular sieves (4-8 mesh, Sigma-Aldrich) after drying with calcium hydride (from Sigma-Aldrich) and distilled. Empty SPE Tube (with frits) volume $3 \mathrm{~mL}$ was used to preparation SPE cartridge packed with synthesized materials. The aqueous solutions were prepared using ultra-pure water from a water purification system (The PURELAB Classic, Elga, UK).

Instruments and analytical conditions. The specific surface area and pore size of silica gel samples were determined using the nitrogen adsorption-desorption method at $77 \mathrm{~K}$ on an ASAP 2020 (Micromeritics, USA). Elemental analyses (\% of carbon, hydrogen and nitrogen $(\mathrm{CHN}))$ of chemically modified silicas were determined by PE-2400 elemental analyzer (Perkin Elmer, USA). Electronic (UV-Vis) absorption spectra (in 200-450 $\mathrm{nm}$ range) were measured by Cary 100 UV-visible spectrophotometer (Agilent, USA). The surface composition of composited was analyzed by X-ray photoelectron spectroscopy (XPS), using a K-alpha X-ray photoelectron spectrometer (Thermo Fisher Scientific, UK) equipped with a hemispherical electron analyzer and an aluminum 
anode $\mathrm{X}$-ray source $(\mathrm{K} \alpha=1486.6 \mathrm{eV})$, providing an energy resolution $\sim 1 \mathrm{eV}$.

Preparation of Working Solutions. The stock standard solution containing $1 \cdot 10^{-3} \mathrm{~mol} \mathrm{~L}^{-1}$ of anthracene in acetonitrile were prepared from weighted mass of anthracene. Then several working standard solutions at $1 \cdot 10^{-5} \mathrm{~mol} \mathrm{~L}^{-1}$ of anthracene were prepared by diluting of stock solution.

The stock solution of MY in acetonitrile at $1 \cdot 10^{-3} \mathrm{~mol} \mathrm{~L}^{-1}$ were prepared from weighted mass of MY. Working solution of MY $2 \cdot 10^{-5} \mathrm{~mol} \mathrm{~L}^{-1}$ was prepared by dilution of its stock solution in acetonitrile water mixture 1:1 (v/v). Solutions of sunflower oil in acetone and heptane $(1 \%)$ were prepared by dilution of the oil in corresponding solvent. The lipidic solutions were spiked with stock solution of anthracene to receive final concentration of contaminant $1 \cdot 10^{-5} \mathrm{~mol} \mathrm{~L}^{-1}$.

Concentration of the anthracene were determined from absorption of leaching solutions at $365 \mathrm{~nm}$ (for acetone) and at $250 \mathrm{~nm}$ (for acetonitrile and heptane) using calibration curve.

Determination of the concentration of grafted groups. Concentrations of functional groups on the surface of the obtained materials were determined
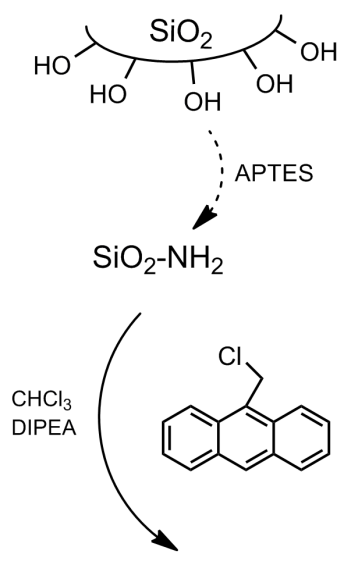

$\mathrm{SiO}_{2}$-Ant-1

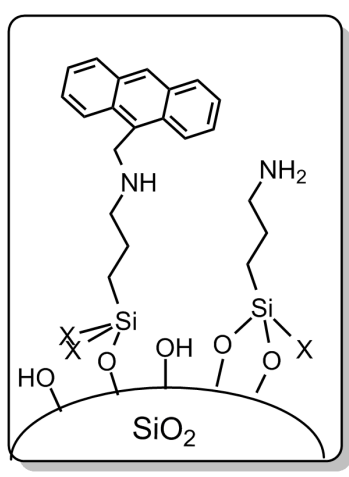

$\mathrm{X}=\mathrm{OEt}, \mathrm{OMe}, \mathrm{OH}$ based on elemental analysis. The concentration of immobilized aminopropyl functional groups $\left(\mathrm{C}_{L}{ }^{\mathrm{NH} 2}\right)$ was calculated from the results of $\mathrm{CHN}$ analysis using equations (1):

$$
C_{L}\left(m_{m o l ~ g}{ }^{-1}\right)=\frac{10 \cdot P_{e}}{A_{r} \cdot n_{e}},
$$

where, is content of the element $(\mathrm{C}$ or $\mathrm{N})$ in \%; is the element atomic mass, is the number of atoms of the element under determination in the grafted fragment.

Since surface of silica gels modified with anthracene groups $\mathrm{SiO}_{2}$-Ant samples contains mixture functional groups, the equation (1) cannot be applied for determination of anthracene fragments loading $\left(C_{L}{ }^{A}\right)$ [21] instead, system of equations (2) shall be applied [22]:

$$
P_{e} / 100=\sum_{i=1}^{i} A_{r}^{i} \cdot n_{e}^{i} \cdot C_{L}^{i}
$$

\section{Synthesis of adsorbents}

General scheme of the adsorbent preparation is presented in Fig. 1.

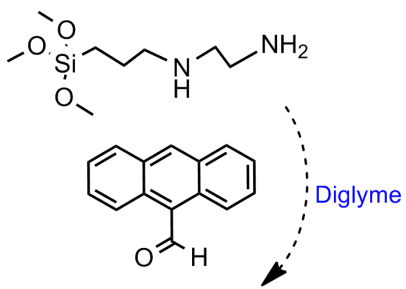

A
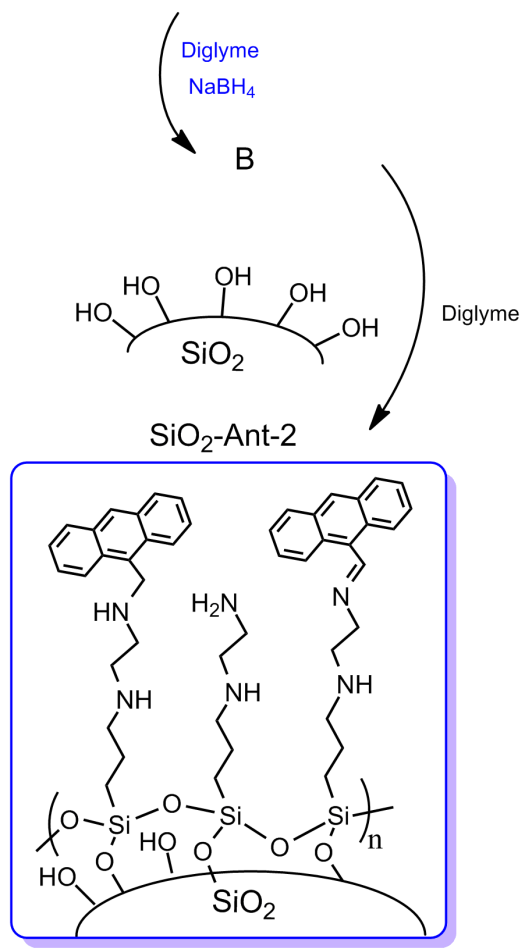

Fig.1. Two synthetic routes for preparation of $\mathrm{SiO}_{2}-\mathrm{Ant}$. 
Silica gel with immobilized aminosilane $\left(\mathrm{SiO}_{2}-\mathrm{NH}_{2}\right)$. As-obtained silica gel was refluxed under agitation in aqueous nitric acid $\mathrm{HNO}_{3}\left(3 \mathrm{~mol} \mathrm{~L}^{-1}\right)$ during $10 \mathrm{~h}$ for purification and activation. Then it was filtered, washed with deionized water and dried at $550^{\circ} \mathrm{C}$ for $5 \mathrm{~h}$. Typically, to $10 \mathrm{~g}$ of the activated silica gel suspended in $100 \mathrm{~mL}$ of dry toluene in a round bottom flask equipped with a magnetic stirrer bar and a reflux condenser, solution of APTES $(3.0 \mathrm{~mL}$ in $70 \mathrm{~mL}$ of dry toluene) was added under constant stirring. The reaction mixture was gently refluxed for $10 \mathrm{~h}$ under stirring. After slowly cooling down to room temperature, the solid phase was separated by filtration, washed in a Soxhlet apparatus with dry toluene. The efficiency of washing procedure was monitored using ninhydrin solution: in the presence of APTES in the supernatant, the color of the solution became blue. After washing the product $\mathrm{SiO}_{2}-\mathrm{NH}_{2}$ was dried at $115^{\circ} \mathrm{C}$ for $7 \mathrm{~h}$ under vacuum.

Silica gel with immobilized anthracene obtained by modification of aminosilane $\mathrm{SiO}_{2}$-Ant-1. Typically, $1.2 \mathrm{~g}$ of $\mathrm{SiO}_{2}-\mathrm{NH}_{2}$ was added under constant agitation to the solution containing mixture of 9CMA $(0.5 \mathrm{~g}$, $2 \mathrm{mmol}$ ) and DIPEA $(3.0 \mathrm{~mL}, 17 \mathrm{mmol})$ in $250 \mathrm{~mL}$ of chloroform at about $0{ }^{\circ} \mathrm{C}$. Then the suspension left at room temperature for about $2 \mathrm{~h}$. After that solid phase was separated by centrifugation and washed with chloroform in apparatus Soxhlet to remove the excess of 9CMA. The completeness of the washing procedure was verified by qualitative test on Cl-ions with copper wire (Beilstein test) and quantitatively from UV-Vis spectroscopic investigation of supernatant on 9CMA presence at $375 \mathrm{~nm}$. Finally, $\mathrm{SiO}_{2}$-Ant-1 was dried under vacuum at $120^{\circ} \mathrm{C}$ for $5 \mathrm{~h}$. Two samples of $\mathrm{SiO}_{2}$-Ant-1 were prepared from $\mathrm{SiO}_{2}-\mathrm{NH}_{2}$ having pores size 6 and $11 \mathrm{~nm}$, annotated as $\mathrm{SiO}_{2}(6)$-Ant-1 and $\mathrm{SiO}_{2}$ (11)-Ant-1, correspondingly.

Synthesis and immobilization of anthracenecontaining silane $\left(\mathrm{SiO}_{2}\right.$-Ant-2). To $60 \mathrm{~mL}$ of diglyme in $100 \mathrm{~mL}$ flask equipped with a magnetic stirrer

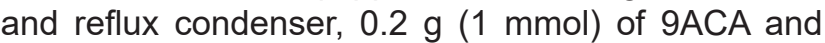
$0.2 \mathrm{~mL}(1 \mathrm{mmol})$ of EDAS was added under stirring. After $12 \mathrm{~h}$ of refluxing, the solution was cooled down to room temperature and $20 \mathrm{~mL}$ solution of $\mathrm{NaBH}_{4}$ $(0.2 \mathrm{~g}, 5 \mathrm{mmol})$ in diglyme was added into the reaction mixture and further stirred at room temperature for $48 \mathrm{~h}$. Resulted light yellow solution was separated from the precipitate by filtration and was transferred in a flask with $\mathrm{SiO}_{2}(11)(1.0 \mathrm{~g})$. The reaction mixture was agitated at $110^{\circ} \mathrm{C}$ for $24 \mathrm{~h}$ under nitrogen atmosphere, then the solid phase was separated and washed in Soxhlet apparatus with chloroform for $24 \mathrm{~h}$ and finally dried at $115^{\circ} \mathrm{C}$ in vacuum. One set of $\mathrm{SiO}_{2}$-Ant-2 was obtained from silica gel having $11 \mathrm{~nm}$ pores size, further annotated as $\mathrm{SiO}_{2}(11)$-Ant-2.

Preparation of packed SPE cartridges. Suspension of $\mathrm{SiO}_{2}$-Ant $(200 \mathrm{mg})$ in $1.5 \mathrm{~mL}$ of $\mathrm{MeOH}$ was transferred into empty SPE cartridge $(3 \mathrm{~mL}$, polypropylene) with polyethylene frit. After adsorbent precipitation it was covered another frit a subtle hand pressure was applied using a cylindrical glass rod, to make the packing compact. The prepared cartridge was stored under solvent before use.

Adsorption studies. Adsorption of PAHs from a model solution has been studied in dynamic mode. For this $3 \mathrm{~mL}$ SPE cartridges packed with $200 \mathrm{mg}$ of $\mathrm{SiO}_{2}$-Ant have been introduced to the flow system, having plunger pump and UV-Vis spectrometer equipped with $0.1 \mathrm{~mL}$ quartz flow-through cuvette, Fig. 2.

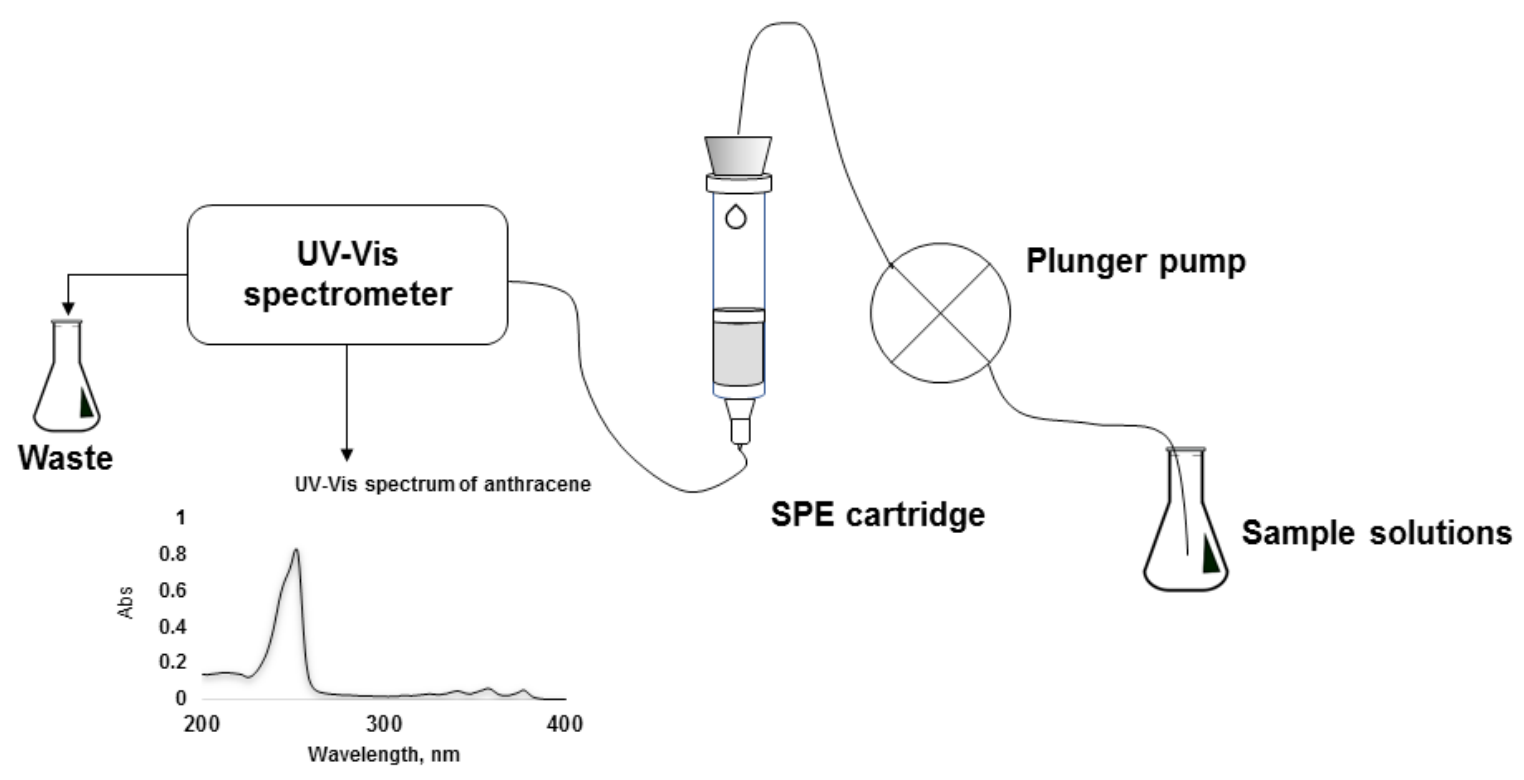

Fig. 2. Schematic diagram of SPE adsorption study. 
The adsorption experiment was performed with flowrate $1 \mathrm{~mL} \mathrm{~min}^{-1}$. The absorption spectra of the solution were recorded in the wavelength range 225-390 nm with scan rate $600 \mathrm{~nm} \mathrm{sec}-1$ and cycled every $0.3 \mathrm{~min}$. The concentration of the analyte in the solution was determined from the calibration curve obtained from anthracene solution at $250 \mathrm{~nm}$ and $365 \mathrm{~nm}$. The dead volume $\left(\mathrm{V}_{\text {dead }}\right)$ of the system was determined from the blank as $V_{\text {dead }}=2.0 \mathrm{~mL}$. The breakthrough curves were obtained by subtracted of $V_{\text {dead }}$ from experimental results.

Adsorption studies of PAHs were performed in the next mobile phases (MP): a) MeCN, b) acetone, c) heptane and d) $\mathrm{MeCN} /$ water $=1 / 1 \mathrm{w} / \mathrm{w}$ at $\mathrm{pH}=3.0$ and 6.0. SPE cartridges were conditioned with water (10 min) and $\mathrm{MeCN}(10 \mathrm{~mL})$. Desorption of anthracene from SPE cartridges has been studied using MeCN and $\mathrm{MeCN} /$ water buffer solution with $\mathrm{pH} 8.5$ (90:10) or acetone.

Three types of model solutions were investigated: a) pure solvents, b) myristic acid (MY. $2 \cdot 10^{-5} \mathrm{~mol} \mathrm{~L}^{-1}$ ) in MeCN:water $(50 \%, \mathrm{pH}=3)$ mixture, and $\mathrm{c})$ solution of commercial sunflower oil ( $1 \%$ in heptane). All solutions were contaminated with anthracene $\left(1 \cdot 10^{-5} \mathrm{~mol} \mathrm{~L}^{-1}\right)$ in the corresponding liquid media.

The effective dynamic adsorption capacity $\left(C_{x}\right)$ of the SPE cartridge was determined for $10 \%, 50 \%$ and $90 \%$ of the cartridge saturation (X) from equation (3):

$$
C_{\mathrm{X}}=\frac{C_{0} * V_{\mathrm{X}}}{m}
$$

where $\mathrm{V}_{\mathrm{x}}$ - volumes of the solution passed through the cartridge to reach corresponding.

Partition coefficient $\left(\mathrm{K}_{\mathrm{d}}\right)$ of anthracene between the solid phase and solution phase is expressed as:

$$
K_{d}=\frac{A d s}{C_{0}}
$$

where Ads - adsorbed concentration of anthracene, $\mathrm{C}_{0}-$ total concentration of anthracene in solution.

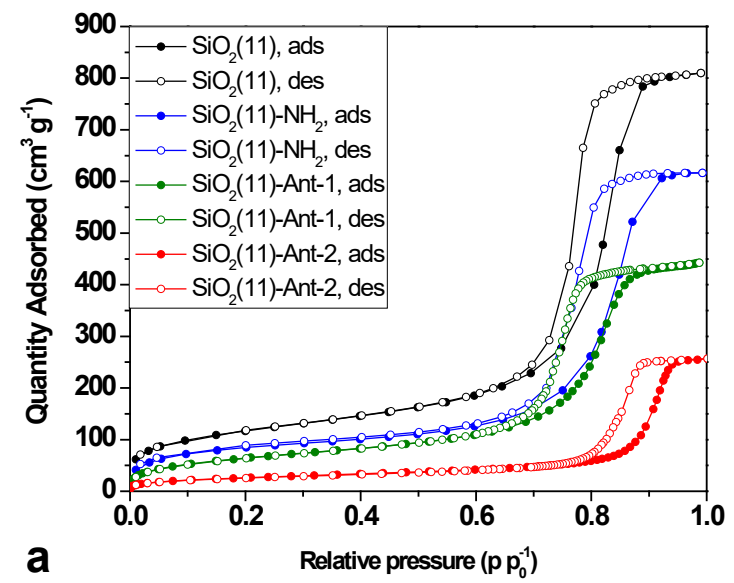

\section{Results and discussion}

\section{Characterization of the adsorbents}

Two approaches were used in $\mathrm{SiO}_{2}$-Ant synthesis: a) surface assembling, where target products were prepared in step-by-step synthesis on silica surface; and b) silane immobilization, where target silane was prepared first and then immobilized on silica surface, Fig. 1. Formation of Schiff base product was a principal step in the synthesis of anthracene-containing silane in the synthetic rout (b). To prevent oligomerization of the alkoxysilane in this rout a Dean-Stark trap was used to collect water produced during a chemical reaction between the aldehyde and the aminosilane (Fig. 1).

Textural characteristics of the materials were determined from on nitrogen adsorption-desorption isotherms, Fig. 3a. The calculated textural parameters for the samples are presented in Table 1.

According to IUPAC classification, our porous samples are close to type IV isotherms and associated with $\mathrm{H} 1$ hysteresis loop type. Such type of the hysteresis loop is related to capillary condensation taking place in mesopores with narrow pore size distributions [23].

Table 1. Textural characteristics of the adsorbents.

\begin{tabular}{llll}
\hline Material & $\mathbf{D}_{\text {BJH }}, \mathbf{n m}$ & $\mathbf{S}_{\mathrm{BET},} \mathbf{m}^{2} \mathbf{g}^{-1}$ & $\begin{array}{l}\mathbf{V}_{\mathbf{p}}^{\text {BJH }} \\
\mathbf{c m}^{3} \mathbf{g}^{-1}\end{array}$ \\
\hline $\mathrm{SiO}_{2}(6)$ & -1 & 480 & $0.80^{\mathrm{b}}$ \\
$\mathrm{SiO}_{2}(6)-\mathrm{NH}_{2}$ & 6.8 & 279 & 0.63 \\
$\mathrm{SiO}_{2}(6)-A n t-1$ & 5.6 & 278 & 0.51 \\
$\mathrm{SiO}_{2}(11)$ & 9.4 & 410 & 1.36 \\
$\mathrm{SiO}_{2}(11)-\mathrm{NH}_{2}$ & 8.4 & 290 & 1.10 \\
$\mathrm{SiO}_{2}(11)-A n t-1$ & 7.8 & 234 & 0.68 \\
$\mathrm{SiO}_{2}(11)-$ Ant-2 & 13 & 95 & 0.39 \\
\hline
\end{tabular}

1 - no data

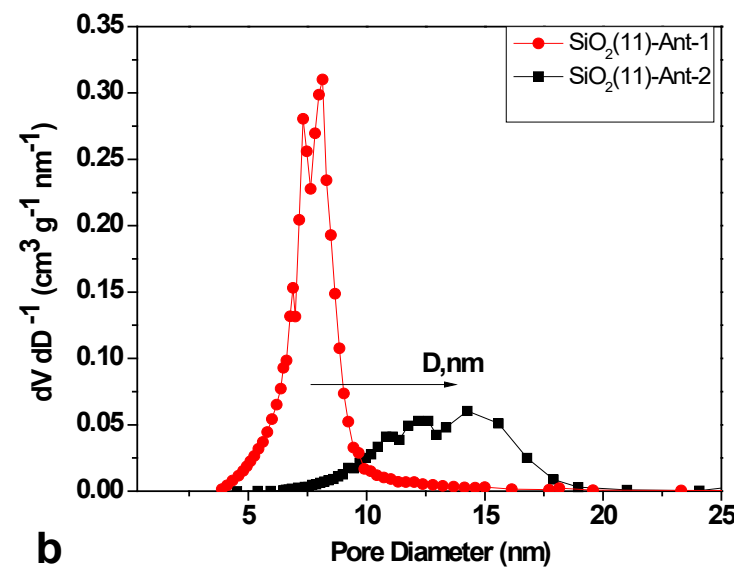

Fig. 3. a) Adsorption and desorption isotherms of $\mathrm{N}_{2}$ on $\mathrm{SiO}_{2}-\mathrm{Ant}$ and parent $\mathrm{SiO}_{2}-\mathrm{NH}_{2}$ and $\mathrm{SiO}_{2}$, b) pore-size distribution in $\mathrm{SiO}_{2}$-Ant-1 and $\mathrm{SiO}_{2}$-Ant-2. 
The presented shape of hysteresis is attributed to cylindrical pores. Surface modification show changes in textural characteristics of pure silica matrix (Table 1). Based on the data, the porosities for the carbon-containing samples and surface area are smaller than for pristine silica. This effect is always observed in the silanization process and is a marker of the immobilization mechanism. Changes in surface area up to $30-40 \%$ indicate silane immobilization in the porous with domination of monolayer bounding. This mechanism probably dominates in $\mathrm{SiO}_{2}$-Ant-1 synthesis, while $\mathrm{SiO}_{2}$-Ant-2 demonstrate essential $(73 \%)$ lost in their specific surface area, indicating multilayer immobilization of pre-polymerized silane [24], Fig. 1.

Chemical composition of the adsorbents was determined from X-ray photoelectron spectroscopy (XPS) and elemental analysis (CHN). The XPS survey scan of anthracene-based silica gels revealed predominantly the presence of matrix component Si2s and $\mathrm{Si} 2 \mathrm{p}, \mathrm{O} 1 \mathrm{~s}$ and modifier components N1s and $\mathrm{C} 1 \mathrm{~s}$. The deconvolution of $\mathrm{C} 1 \mathrm{~s}$ high resolution XPS spectrum of $\mathrm{SiO}_{2}$-Ant (Fig. 4) reveals three spectral components in the range 282-290 eV. Based on energy position these peaks can be attributed to the next bonds: C-O (287.6 - 288.2 eV), C-N (286 - 286.4 eV), and C-C/C-H (285 - 285.1), respectively [25]. In addition, both samples ( $\mathrm{SiO}_{2}$-Ant-1 and $\mathrm{SiO}_{2}$-Ant-2) demonstrate peak with binding energy at $292.0 \mathrm{eV}$ (Fig.4), indicating the presence of conjugated aromatic system that can be assigned to anthracene fragments [26].

Concentration of residual aminopropyl $\left(C_{N H 2}^{\prime}\right)$ and target anthracene $\left(C_{L}{ }^{A}\right)$ groups on different samples of $\mathrm{SiO}_{2}$-Ant was determined from $\mathrm{CHN}$ analysis using equations (2). The results presented in the Table 2 demonstrate that all samples of $\mathrm{SiO}_{2}$-Ant have bimodal composition of the immobilized layer with balanced combination of lipophilic anthracene and hydrophilic aminopropyl fragments.

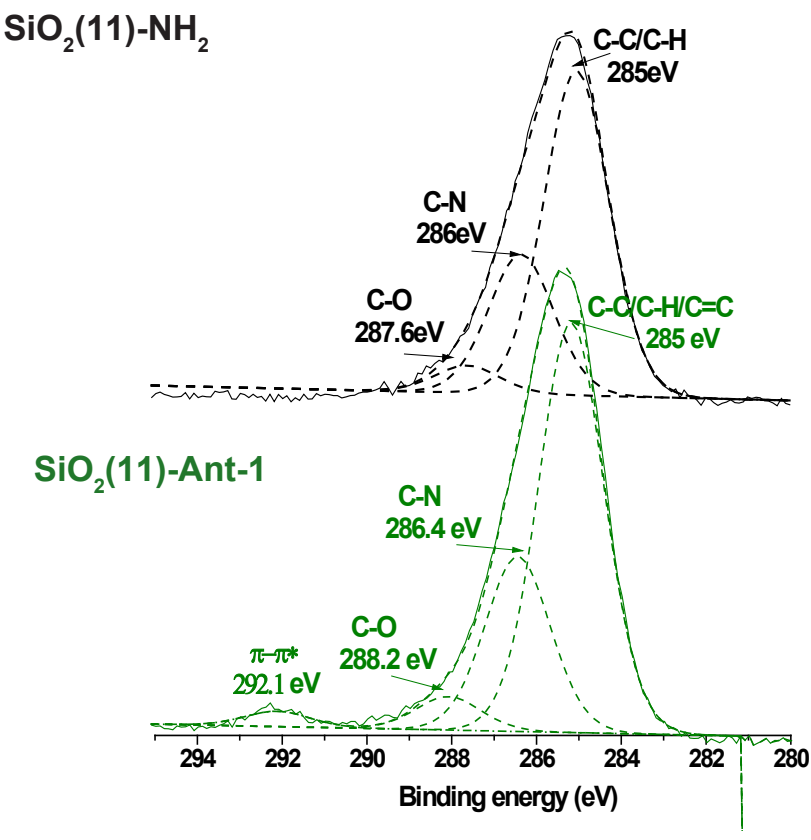

a

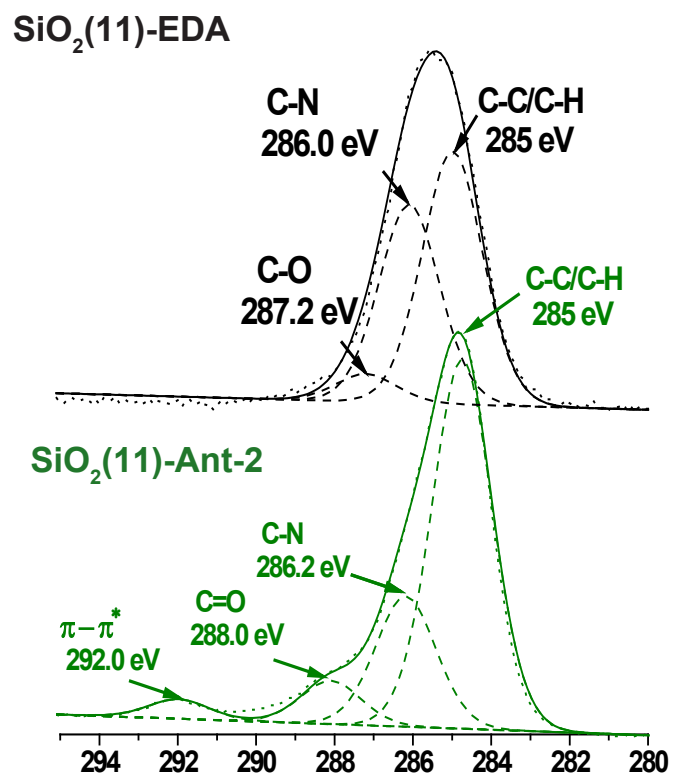

b

Fig. 4. a) High-resolution $\mathrm{C} 1 \mathrm{~s}$ spectra of pair $\mathrm{SiO}_{2}(11)-\mathrm{NH}_{2}$ and $\mathrm{SiO}_{2}(11)-\mathrm{Ant}-1$ and b) $\mathrm{SiO}(11)-\mathrm{EDA}$ and $\mathrm{SiO}_{2}(11)-$ Ant-2.

Table 2. The results of elemental analysis.

\begin{tabular}{|c|c|c|c|c|c|c|c|}
\hline Material & $\begin{array}{l}\mathbf{N}, \\
\%\end{array}$ & $\begin{array}{l}\mathrm{C}, \\
\% \\
\end{array}$ & $\begin{array}{l}\mathrm{H}, \\
\% \\
\end{array}$ & $\begin{array}{c}\mathrm{C}_{\mathrm{NH}^{\prime}} \\
\mathrm{mmol} \cdot \mathrm{g}^{-1}\end{array}$ & $\begin{array}{c}C_{L}{ }^{A}, \\
\mathrm{mmol} \cdot \mathrm{g}^{-1}\end{array}$ & $\begin{array}{c}C_{N H 2^{\prime}}^{\prime} \\
\mu \mathrm{mol} \cdot \mathrm{m}^{2}\end{array}$ & $\begin{array}{c}C_{L}{ }^{A}, \\
\mu \mathrm{mol} \cdot \mathrm{m}^{2}\end{array}$ \\
\hline $\mathrm{SiO}_{2}(6)-\mathrm{Ant}-1$ & 1.14 & 6.10 & 0.98 & 0.63 & 0.18 & 2.3 & $0.65(22 \%)$ \\
\hline $\mathrm{SiO}_{2}(11)-\mathrm{Ant}-1$ & 1.05 & 4.61 & 0.80 & 0.64 & 0.11 & 2.7 & $0.47(15 \%)$ \\
\hline $\mathrm{SiO}_{2}(11)-\mathrm{Ant}-2$ & 2.13 & 9.12 & 3.87 & 0.51 & 0.25 & 5.3 & $2.6(33 \%)$ \\
\hline
\end{tabular}


The adsorbents obtained in the surface assembling synthesis $\left(\mathrm{SiO}_{2}\right.$-Ant-1) have smaller segment the target anthracene groups (up to $22 \%$ ) than that obtained in one-step silane immobilization (33\%). It seems that enlargement of the pore size does not increase loading of the anthracene on $\mathrm{SiO}_{2}-\mathrm{Ant}-1$. Finally, average density of the immobilized layer $\left(\mu \mathrm{mol} \mathrm{m}^{2}\right)$ calculated as sum of and increases with pore size enlargement and for $\mathrm{SiO}_{2}(11)$-Ant-2 is higher than maximum density of monolayer indicating multilayer immobilization.

\section{Adsorption studies}

The performance of SPE cartridges in adsorption of anthracene from model solution has been studied from breakthrough curves. Particularly next parameters of the curves were determined for all adsorbents: a) the breakthrough point $\left(\mathrm{C}_{10 \%}\right)$, when the concentration of analyte $\left(\mathrm{C}_{x}\right)$ in eluate reached 0.1 of $\left.\mathrm{C}_{0} ; \mathrm{b}\right)$ the dynamic capacity of the column $\left(\mathrm{C}_{50 \%}\right)$, when $\mathrm{C}_{\mathrm{x}}=0.5 \mathrm{C}_{0}$; and c) the operation limit of the column $\left(\mathrm{C}_{90 \%}\right)$. Adsorption studies were performed in the next mobile phases: acetonitrile, acetonitrile:water $=1: 1(\mathrm{v} / \mathrm{v})$, acetone and heptane.

It is obvious that, because its hydrophobic nature, C18 cartridge recovers PAHs from water media better than any other more hydrophilic adsorbent, including $\mathrm{SiO}_{2}$-Ant. Fig. 5 demonstrates that in acetonitrile/ water mixture both the breakthrough point $\left(\mathrm{C}_{10 \%}\right)$ and dynamic adsorption capacity of C18 cartridge are much higher than for $\mathrm{SiO}_{2}$-Ant-2.

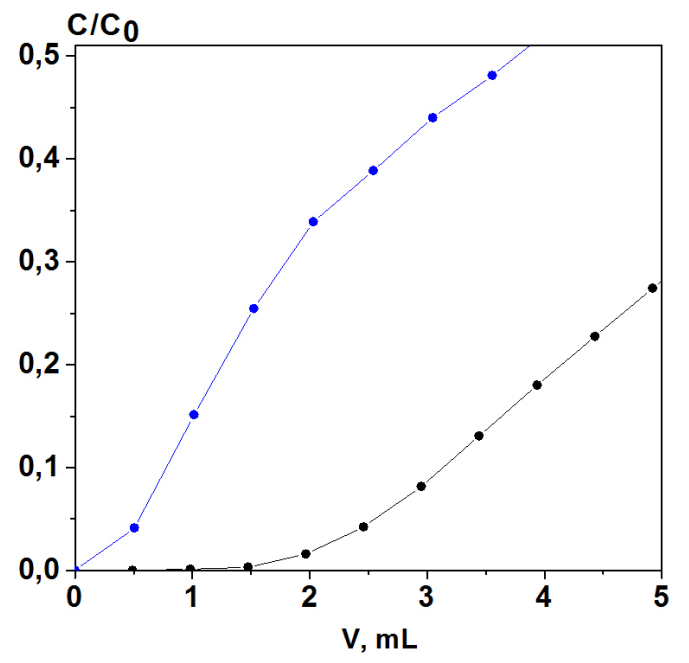

a

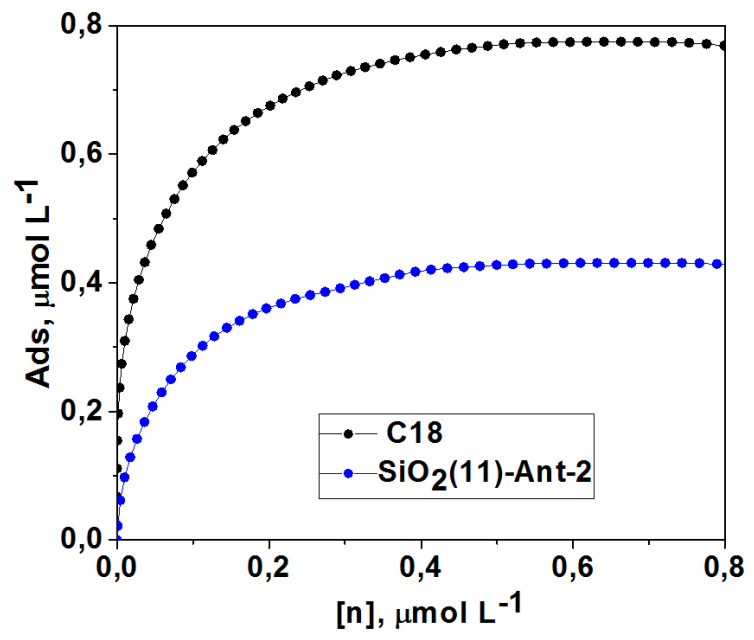

b

Fig. 5. a) Breakthrough curves of anthracene from its solution in $\mathrm{MeCN}: \mathrm{H}_{2} \mathrm{O}=1: 1$ (v/v) mixture with $\mathrm{pH}=3.0$ and b) dynamic adsorption capacity of SPE the cartridges.

Table 3. Parameters of the breakthrough curves of anthracene (ANT) solution $\left(10^{-5} \mathrm{~mol} \mathrm{~L}^{-1}\right)$ in various mobile phases: the breakthrough point $\left(\mathrm{C}_{10 \%}\right)$, the dynamic capacity of the column $\left(\mathrm{C}_{50 \%}\right)$, the operation limit of the column $\left(\mathrm{C}_{90 \%}\right)$ and partition coefficient $\left(\mathrm{K}_{\mathrm{d}}\right)$.

\begin{tabular}{|c|c|c|c|c|c|}
\hline \multirow{2}{*}{ Mobile phase } & \multirow{2}{*}{ Adsorbent } & $\mathbf{C}_{10 \%}$ & $\mathrm{C}_{50 \%}$ & $\mathrm{C}_{90 \%}$ & \multirow{2}{*}{$\begin{array}{l}\mathbf{K}_{\mathrm{d}} \\
\mathbf{m L} \mathbf{g}^{-1}\end{array}$} \\
\hline & & \multicolumn{3}{|c|}{$\mathrm{nmol} \mathrm{g}^{-1}$} & \\
\hline ANT in $\mathrm{CH}_{3} \mathrm{CN} / \mathrm{H}_{2} \mathrm{O}$ & C18 & 239 & 582 & 987 & 4870 \\
\hline $\begin{array}{c}\text { ANT and } \mathrm{MY}\left(2 \cdot 10^{-5}\right) \text { in } \\
\mathrm{CH}_{3} \mathrm{CN} / \mathrm{H}_{2} \mathrm{O}\end{array}$ & C18 & 158 & 400 & 900 & 3860 \\
\hline ANT in $\mathrm{CH}_{3} \mathrm{CN} / \mathrm{H}_{2} \mathrm{O}$ & $\mathrm{SiO}_{2}(11)-A n t-2$ & 33 & 64 & 981 & 2920 \\
\hline $\begin{array}{c}\text { ANT and } \mathrm{MY}\left(2 \cdot 10^{-5}\right) \text { in } \\
\mathrm{CH}_{3} \mathrm{CN} / \mathrm{H}_{2} \mathrm{O}\end{array}$ & $\mathrm{SiO}_{2}(11)$-Ant-2 & 38 & 185 & 564 & 3060 \\
\hline \multirow[t]{3}{*}{ ANT in $\mathrm{CH}_{3} \mathrm{CN}$} & C18 & 13 & 52 & 229 & 2260 \\
\hline & $\mathrm{SiO}_{2}(11)-$ Ant-1 & 6.0 & 35 & 108 & 1770 \\
\hline & $\mathrm{SiO}_{2}(11)-$ Ant-2 & 36 & 74 & 153 & 3160 \\
\hline \multirow[t]{3}{*}{ ANT in Acetone } & C18 & 14 & 55 & 237 & 1690 \\
\hline & $\mathrm{SiO}_{2}(11)-$ Ant-1 & 7.4 & 34 & 113 & 1530 \\
\hline & $\mathrm{SiO}_{2}(11)$-Ant-2 & 40 & 74 & 163 & 2290 \\
\hline
\end{tabular}


Nevertheless, increasing the mobile phase lipophilicity sharply reduce affinity of C18 adsorbent towards PAHs. For example, in acetonitrile and acetone breakthrough points of anthracene for C18 cartridges decrease about 10 times from 158 to $14 \mathrm{nmol} \mathrm{g}^{-1}$, Table 3 . The column operating limit $\left(\mathrm{C}_{90 \%}\right)$ and partition coefficients $\left(\mathrm{K}_{\mathrm{d}}\right)$ also essentially decreased for $\mathrm{C} 18$ cartridge, while for the proposed adsorbents $\mathrm{C}_{10 \%}$ and other parameters of the dynamic adsorption do not undergo essential changes. It is important to mention that adsorption characteristics of $\mathrm{SiO}_{2}$-Ant-2 to anthracene in organic solvent is essentially better than $\mathrm{SiO}_{2}$-Ant-1 and even $\mathrm{C} 18$, Table 3. Considering that $\mathrm{SiO}_{2}-$ Ant-2 has a higher loading of anthracene fragments, this fact indicates importance of $\pi-\pi$ interaction in adsorption properties of the investigated materials.

Adsorption of anthracene form lipidic solutions

Since dispersive interactions determine adsorption of chemicals on C18 phases, even small quantity of lipophilic compounds essentially reduce affinity of C18 SPE cartridge towards PAHs, even in water-containing media. Indeed, even two-fold excess of myristic acid added as competitive compound to acetonitrile/water solution of anthracene reduces concentration of anthracene breakthrough point on C18 from 239 to $158 \mathrm{nmol} \mathrm{g}^{-1}$. Contrary, in similar conditions values of $\mathrm{C}_{10 \%}, \mathrm{C}_{50 \%}$ and $\mathrm{K}_{\mathrm{d}}$ even increased for $\mathrm{SiO}_{2}(11)$-Ant-2 (Table 3) confirming intramolecular $\pi-\pi$ interaction, as dominating mechanism of adsorption.

Considering the data received, adsorption of
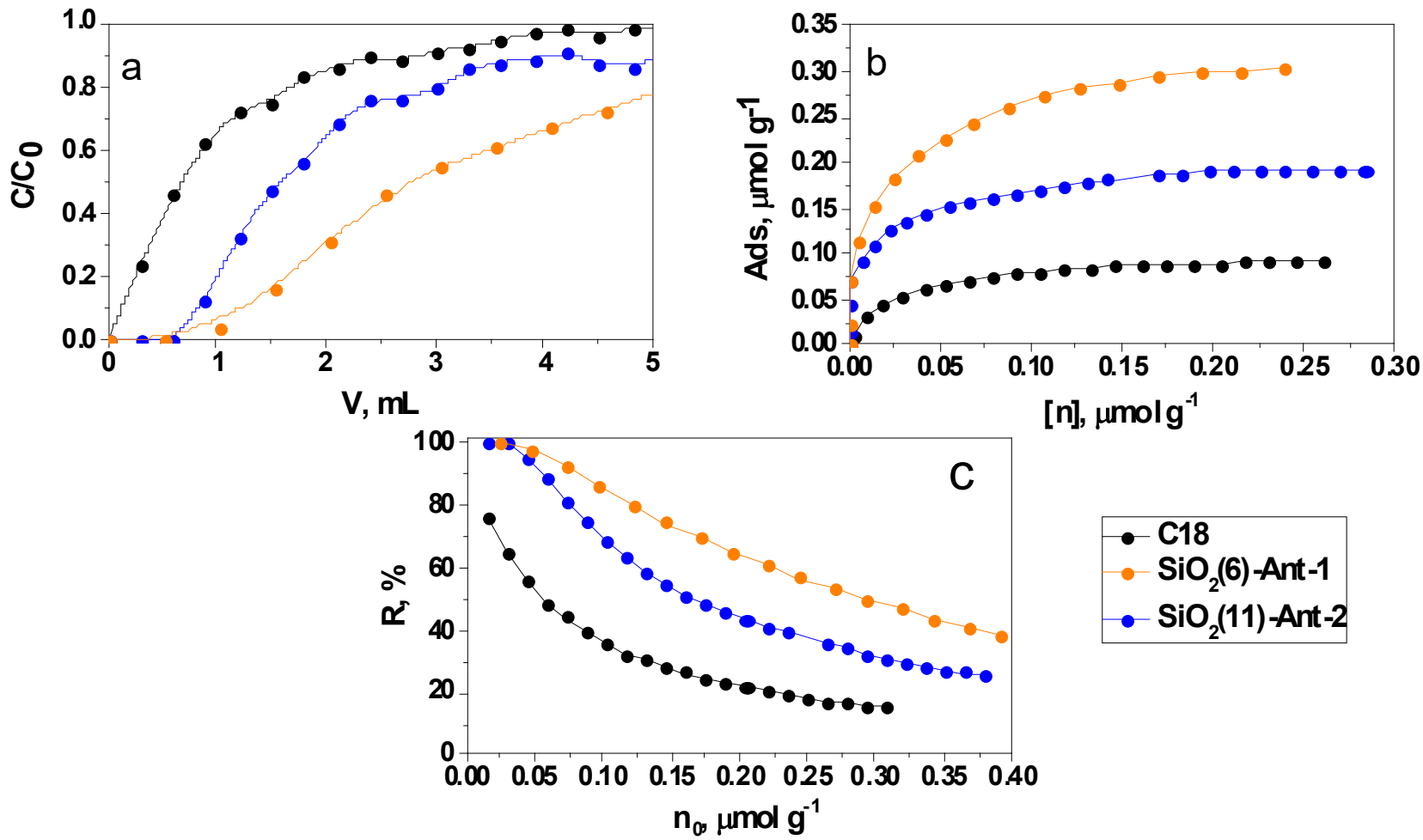

Fig. 6. Dynamic adsorption of anthracene from $1 \%$ solution of sunflower oil in acetone, contaminated with $1 \cdot 10^{-5} \mathrm{~mol} \mathrm{~L}^{-1}$ of anthracene: a) the breakthrough curves, b) dynamic adsorption capacity of SPE the cartridges, c) recovery. 
Table 4. Parameters of the breakthrough curves of anthracene from $1 \%$ solution of spiked sunflower oil in acetone and heptane.

\begin{tabular}{|c|c|c|c|c|}
\hline \multirow{2}{*}{ Adsorbent } & $\mathrm{C}_{10 \%}$ & $\mathbf{C}_{50 \%}$ & $\mathrm{C}_{90 \%}$ & \multirow{2}{*}{$\begin{array}{c}\mathrm{K}_{\mathrm{d}^{\prime}} \\
\mathrm{mL} \mathrm{g}^{-}\end{array}$} \\
\hline & \multicolumn{3}{|c|}{$\mathrm{nmol} \mathrm{g}^{-1}$} & \\
\hline \multicolumn{5}{|c|}{ Acetone } \\
\hline C18 & 6 & 36 & 104 & 1327 \\
\hline $\mathrm{SiO}_{2}(6)-A n t-1$ & 29 & 63 & 178 & 2733 \\
\hline $\mathrm{SiO}_{2}(11)-A n t-1$ & 20 & 46 & 113 & 1626 \\
\hline $\mathrm{SiO}_{2}(11)$-Ant-2 & 23 & 56 & 140 & 1512 \\
\hline \multicolumn{5}{|c|}{ Heptane } \\
\hline C18 & 5 & 35 & 143 & 1306 \\
\hline $\mathrm{SiO}_{2}(6)-\mathrm{Ant}-1$ & 57 & 134 & 316 & 3714 \\
\hline $\mathrm{SiO}_{2}(11)-A n t-2$ & 44 & 74 & 207 & 2270 \\
\hline
\end{tabular}

\section{Conclusions}

Thus, in contrast to $\mathrm{C} 18, \mathrm{SiO}_{2}$-Ant can adsorb $\mathrm{PAHs}$ from lipidic solutions in non-polar solvents. The adsorbent selectivity can be caused by its ability to form intermolecular $\pi-\pi$ complexes with to PAHs. The adsorbents do not demonstrate selectivity towards lipophilic macrocomponents such as MY and sunflower oil. This can be explained by hydrophilicity of $\mathrm{SiO}_{2}-\mathrm{Ant}$, which have only about $15-33 \%$ of lipophilic fragments, Fig. 7. Therefore, when adsorption of the aromatics occurs due to non-selective hydrophobic interaction (for example in acetonitrile/water media), $\mathrm{SiO}_{2}$-Ant demonstrated feeble adsorption properties. Contrary, in apolar solvents $\mathrm{SiO}_{2}$-Ant demonstrate specific adsorption of aromatics due to $\pi-\pi$ interaction.

\section{References}

1. Xu, T.; Tang, H.; Chen, D.; et al. Simultaneous Determination of 24 Polycyclic Aromatic Hydrocarbons in Edible Oil by Tandem Solid-Phase Extraction and Gas Chromatography Coupled/Tandem Mass Spectrometry. J. AOAC Int. 2015, 98 (2), 529-537.

2. Moret, S.; Conte, L. S. Polycyclic Aromatic Hydrocarbons in Edible Fats and Oils: Occurrence and Analytical Methods. J. Chromatogr. A 2000, 882 (1-2), 245-253.

3. Abdel-Shafy, H. I.; Mansour, M. S. M. A Review on Polycyclic Aromatic Hydrocarbons: Source, Environmental Impact, Effect on Human Health and Remediation. Egypt. J. Pet. 2016, 25 (1), 107-123.

4. Serpe, F. P.; Esposito, M.; Gallo, P.; et al. Optimisation and Validation of an HPLC Method for Determination of Polycyclic Aromatic Hydrocarbons (PAHs) in Mussels. Food Chem. 2010, 122 (3), 920-925.

5. Purcaro, G.; Moret, S.; Conte, L. S. Rapid SPE-HPLC Determination of the 16European Priority Polycyclic Aromatic Hydrocarbons in Olive Oils. $J$. Sep. Sci. 2008, 31 (22), 3936-3944.

6. Jira, W. A GC/MS Method for the Determination

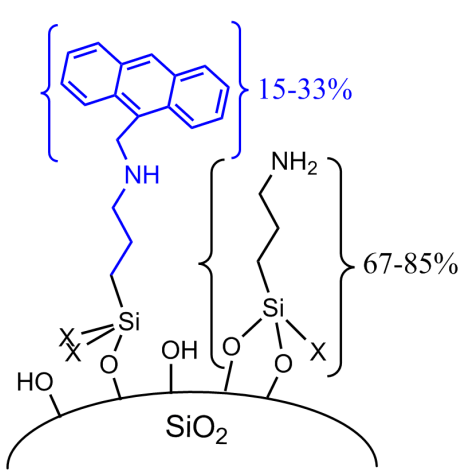

Fig.7. Composition of the immobilized layer on $\mathrm{SiO}_{2}$-Ant adsorbents.

\section{Acknowledgments}

The authors are grateful for the financial support of this research obtained from Coordenação de Aperfeiçoamento de Pessoal de Nível Superior (CAPES), Brazil (Finance Code 001), Conselho Nacional de Desenvolvimento Científico e Tecnológico (CNPq), Brazil (grant 304622/2015-0, 306992/2018-3, and 438450/2018-3) and Fundação Carlos Chagas Filho de Amparo à Pesquisa do Estado do Rio de Janeiro (FAPERJ) (Grant E-26/010.000978/2019). A.M. is grateful to CNPq (154820/2015-6) and (FAPERJ) (E-26/200.612/2018) for the conceded fellowships. We also appreciate the generous help received from Prof. Edilson V. Benvenutti (IQUFRGS) in BET measurements and technical support from Brazilian Nanotechnology National Laboratory (LNNano) in XPS. In addition, we thank Prof. Ricardo Q. Aucélio (PUC-Rio) for technical support in $\mathrm{CHN}$ measurements.

of Carcinogenic Polycyclic Aromatic Hydrocarbons (PAH) in Smoked Meat Products and Liquid Smokes. Eur. Food Res. Technol. 2004, 218 (2), 208-212.

7. Dost, K.; Deli, C. Determination of Polycyclic Aromatic Hydrocarbons in Edible Oils and Barbecued Food by HPLC/UV-Vis Detection. Food Chem. 2012.

8. Andrade-eiroa, A.; Canle, M.; Leroycancellieri, V.; et al. Trends in Analytical Chemistry Solid-Phase Extraction of Organic Compounds: A Critical Review ( Part I ). Trends Anal. Chem. 2016, 80, 641-654.

9. Moret, S.; Conte, L. S. A Rapid Method for Polycyclic Aromatic Hydrocarbon Determination in Vegetable Oils. J. Sep. Sci. 2002, 25 (1/2), 96-100.

10. Helcom. Guidelines for the Determination of Polycyclic Aromatic Hydrocarbons (PAHs) in Biota; 1998.

11. Liguori, L.; Heggstad, K.; Hove, H. T.; et al. An Automated Extraction Approach for Isolation of 24 Polyaromatic Hydrocarbons (PAHs) from Various Marine Matrixes. Anal. Chim. Acta 2006.

12. Purcaro, G.; Barp, L.; Moret, S. Determination of Hydrocarbon Contamination in Foods. A Review. Analytical Methods. 2016. 
13. Stenerson, K. K.; Shimelis, O.; Halpenny, M. R.; et al. Analysis of Polynuclear Aromatic Hydrocarbons in Olive Oil after Solid-Phase Extraction Using a Dual-Layer Sorbent Cartridge Followed by High-Performance Liquid Chromatography with Fluorescence Detection. J. Agric. Food Chem. 2015, 63 (20), 4933-4939.

14. Welling, P.; Kaandorp, B. Determination of Polycyclic Aromatic Hydrocarbons (PAH) in Edible Vegetable Oils by Liquid Chromatography and Programmed Fluorescence Detection Comparison of Caffeine Complexation and XAD-2 Chromatography Sample Clean-Up. Z. Lebensm. Unters. Forsch. 1986, 183 (2), 111-115.

15. Gadzała-Kopciuch, R. M.; Kluska, M.; Welniak, M.; et al. Aryl Chemically Bonded Phases for Determination of Selected Polycyclic Aromatic Hydrocarbons Isolated from Environmental Samples Utilizing SPE/HPLC. Polish J. Environ. Stud. 1999, 8 (6), 383-387.

16. Hoeben, F. J. M.; Jonkheijm, P.; Meijer, E. W.; et al. About Supramolecular Assemblies of п-Conjugated Systems. Chem. Rev. 2005, 105 (4), 1491-1546.

17. Zhang, Y.; Li, Q.; Zhong, $\mathrm{H}_{\text {.; }}$ et al. Tuning Selectivity via Electronic Interaction: Preparation and Systematic Evaluation of Serial Polar-Embedded Aryl Stationary Phases Bearing Large Polycyclic Aromatic Hydrocarbons. Anal. Chim. Acta 2018, 1036, 162-171. 18. Oh, S. Y.; Kim, K. P.; Jung, M. W.; et al. Selective Solid-Phase Extraction of Polycyclic Aromatic Hydrocarbons by the Chemically Modified Polymeric Adsorbents with Protoporphyrin IX. Chromatographia 2003, 57 (9-10), 665-670.
19. Liu, Q.; Shi, J.; Jiang, G. Application of Graphene in Analytical Sample Preparation. TrAC Trends Anal. Chem. 2012, 37, 1-11.

20. Zhao, Q.; Wei, F.; Luo, Y. B.; et al. Rapid Magnetic Solid-Phase Extraction Based on Magnetic Multiwalled Carbon Nanotubes for the Determination of Polycyclic Aromatic Hydrocarbons in Edible Oils. J. Agric. Food Chem. 2011.

21. Zaitsev, V. N. Complexing Silicas: Preparation, Structure of Bonded Layer, Surface Chemistry; Folio: Kharkiv, 1997.

22. Artiushenko, O.; Ávila, E. P.; Nazarkovsky, M.; et al. Reusable Hydroxamate Immobilized Silica Adsorbent for Dispersive Solid Phase Extraction and Separation of Rare Earth Metal Ions. Sep. Purif. Technol. 2020, 231, 115934.

23. Daigle, H. Microporosity Development in Shallow Marine Sediments from the Nankai Trough. Mar. Geol. 2014, 357, 293-303.

24. Bio-Inorganic Hybrid Nanomaterials: Strategies, Synthesis, Characterization and Applications; Ruiz-Hitzky, E., Ariga, K., Lvov, Y. M., Eds.; John Wiley \& Sons, Inc., 2008.

25. Permatasari, F. A.; Aimon, A. H.; Iskandar, F.; et al. Role of $\mathrm{C}-\mathrm{N}$ Configurations in the Photoluminescence of Graphene Quantum Dots Synthesized by a Hydrothermal Route. Sci. Rep. 2016, 6 (1), 21042.

26. Moulder, J. F.; Stickle, W. F.; Sobol, P. E.; et al. Handbook of X-Ray Photoelectron Spectroscopy: A Reference Book of Standard Spectra for Identification and Interpretation of XPS Data; Chastain, J., Ed.; Eden Prairie, Minn. : Perkin-Elmer Corporatioon, Physical Electronics Division, 1992. 